\title{
SLITRK1 wt Allele
}

National Cancer Institute

\section{Source}

National Cancer Institute. SLITRK1 wt Allele. NCI Thesaurus. Code C90129.

Human SLIT RK1 wild-type allele is located in the vicinity of $13 q 31.1$ and is approximately 5 $\mathrm{kb}$ in length. This allele, which encodes SLIT and NT RK-like protein 1, plays a role in the modulation of neuronal morphology. Mutation of the gene may be associated with Gilles de la Tourette syndrome. 